Токар П.В.,

кандидат соииологических наук,

зарубежньй преподаватель кафедр сочиологии

и международных отномений, почётный профессор

Евразийского наџионального университета им. Л.Н. Гумилёва

(2. Астана, Казахстан)

\title{
СОСТОЯНИЕ И ПЕРСПЕКТИВЫ РАЗВИТИЯ НАУЧНО-ТЕХНИЧЕСКОГО СОТРУДНИЧЕСТВА УКРАИНЫ И РЕСПУБЛИКИ КАЗАХСТАН
}

Тенденции инновационного развития экономики в условиях интеграции в международное экономическое пространство требуют адекватной внешнеэкономической политики, направленной на определение приоритетных направлений развития страны, где средствами достижения международной конкурентоспособности выступают высокотехнологичные инновации. Сложившаяся в Украине политика в научно-технической сфере способствует инновационному развитию, определяет степень научнотехнического сотрудничества Украины со странами мира, в том числе с Республикой Казахстан. Практическая целесообразность развития научнотехнического сотрудничества, начиная с 2000-х годов нашла понимание со стороны украинского руководства, что отразилось в подписании ряда двусторонних нормативно-правовых соглашений, договоров, программ. Результатом стало и украинско-казахстанское сотрудничество в сфере науки и технологий, решение общих вопросов в области научно-технической деятельности, а самое главное - формирование и признание научнотехнологического потенциала и его привлечение к международной научнотехнологической кооперации.

Отношения между двумя странами в этой области закреплены в сложившейся законодательной базе и основаны на договорах: о дружбе и сотрудничестве между Украиной и Республикой Казахстан от 20 января 1994 года; об экономическом сотрудничестве на 1999-2009 годы (действующий и пролонгированный), и соглашениях: «О научнотехническом сотрудничестве в рамках государств-участников Содружества Независимых Государств» (13.03.1992 года) между Правительством Украины и Правительством Республики Казахстан, «О сотрудничестве в сфере науки и технологий» (21.09.1995 года) между Министерством образования и науки Украины и Министерством образования и науки Республики Казахстан о сотрудничестве в области образования и науки (14.09.2010 года) и многие другие. Также среди заключенных документов стоит выделить так называемые «Дорожные карты» - «Планы действий Украина-Казахстан», подписанные в 2005, 2007, 2010, 2013, 2015 годах для улучшения сотрудничества в топливно-энергетическом комплексе, сфере транспорта, агропромышленном комплексе, сфере космической деятельности, сферах торговли и инвестиций [1]. 
К сожалению, научно-техническое сотрудничество в 90-х годах между двумя странами почти не осуществлялось, поскольку его основные направления, помимо согласования на межгосударственном уровне, требовали еще больших капиталовложений, что в период восстановления после распада Советского союза было сложным для обеих сторон. Частные предприниматели также не спешили развивать эту сферу.

Ситуация стала меняться с развитием нефте- и газодобывающей отрасли в Казахстане, где в начале 2000-х годов наметился дефицит специалистов и технологий в области металлообработки, машиностроения, авиационной и космической отраслях, поэтому перспективным для Украины стало участие украинских компаний в качестве подрядчиков, поставщиков оборудования и сервисных услуг в рамках создания и модернизации вышеуказанных отраслей экономики. Большие возможности открывались для сотрудничества в научно-техническом направлении в связи со Стратегией развития Казахстана до 2010 года, которая предусматривала на базе финансовых накоплений от экспорта нефти и сырья для чёрной и цветной металлургии существенно расширить собственное технологическое производство. В частности, в металлургии - освоить производство железнодорожных пассажирских вагонов, тепло- и электровозов, тракторов, оборудования для нефтегазовой отрасли.

В начале 2000-х годов стороны приступили к реализации ряда проектов, работа над которыми продолжается и сегодня. В ходе 4-го заседания (2001 год) Совместной межгосударственной комиссии по экономическому сотрудничеству достигнута договоренность относительно направлений научно-технического сотрудничества в области ядерной энергетики, космоса, добычи газа. Одним из них является конверсионная программа «Днепр», которая предусматривает создание и использование космического ракетного комплекса на космодроме «Байконур» на базе межбалистических ракет РР20, которые подлежали ликвидации. Реализация программы возложена на украинско-российское предприятие «Международная космическая компания «Космотрас». Во время посещения Президентом Казахстана Н. Назарбаева г. Днепропетровска в июне 2000 года было достигнуто принципиальное согласие о присоединении страны к реализации этой программы, но при условии участия казахстанских специалистов в технологических операциях, проводимых на объектах космодрома «Байконур» [2].

Важную роль в развитии научно-технического сотрудничества между Украиной и Казахстаном в настоящее время играет Украинский центр науки и культуры (далее - УЦНК) при Посольстве Украины, созданный в сентябре 2011 года по инициативе украинского дипломатического учреждения на базе Евразийского национального университета им. Л.М. Гумилева. Основными направлениями деятельности УЦНК является: развитие двустороннего сотрудничества между Украиной и Казахстаном в сфере науки, образования и культуры, поиск механизмов реализации договоренностей о сотрудничестве, содействие украинской диаспоре в научно-методическом обеспечении их деятельности, содействие углублению контактов учёных, 
преподавателей и студентов ЕНУ и других вузов РК с вузами Украины, а с 2014 года и с вузами Европы. Для реализации этой работы на базе УЦНК действует научно-методический совет, созданный из числа видных учёных и деятелей разных областей науки, образования и культуры Казахстана.

При содействии УЦНК только в 2012 году на обучение в вузы Украины по программе бакалавриата на грантовой основе поступили 53 казахстанских граждан, в том числе 15 из них - рекомендованных украинскими общинами РК, и 12 - по программе магистратуры. 25 абитуриентов на контрактной основе вступили в НТУУ «КПИ» и другие технические вузы Украины. На выделенные МОН РК гранты четверо украинских студентов поступили на обучение в магистратуру ЕНУ им. Л.Гумилева. Кроме этого, по договоренности Украинского центра и ректората ЕНУ 24 студента из четырех вузов Украины - партнеров ЕНУ прошли бесплатное обучение на различных факультетах и два в докторантуре этого университета, а 26 студентов и преподавателей КНУ им. Т. Шевченко по приглашению Президента РК Н. Назарбаева, прошли стажировку и провели Дни науки в ЕНУ им. Л. Гумилёва.

Одним из показателей успешного сотрудничества является публикация статей и докладов украинских ученых в престижном в РК научнопублицистическом журнале «Манги Ел» (Вечное государство), других научных сборниках, научных вестниках вузов РК, а также казахстанских учёных в Украине.

В течение 2013 года были осуществлены продуктивные шаги по развитию двустороннего сотрудничества в сфере науки и новых технологий. В частности, 4 апреля в рамках встречи премьер-министров Украины и Республики Казахстан была подписана программа сотрудничества в области науки и технологий между Государственным агентством по вопросам науки, инноваций и информатизации Украины и Министерством образования и науки Республики Казахстан на 2013-2017 годы. В рамках программы стороны развивают сотрудничество по следующим направлениям: информационные и коммуникационные технологии, науки о жизни, энергетика и энергоэффективность, глубокая переработка сырья и новые вещества и материалы, рациональное природопользование. Сотрудничество предполагает выполнение совместных научно-исследовательских и технических проектов, обмен учеными, организацию совместных конференций, симпозиумов, курсов и семинаров, обмен научной и технической информацией, документами и др.

Активную работу по налаживанию сотрудничества в науке и технологиях проводит Посольство Казахстана в Украине. При его посредничестве были установлены связи Научно-технологического парка КазНУ имени Аль-Фараби с Международной академией наук и технологий Украины, специалисты которого с рабочим визитом побывали в Астане в августе 2014 г. Посольство Украины регулярно организовывает презентации украинских высокотехнологичных проектов ГП «Научно-производственный комплекс газотурбостроения (ГП НПКГ) «Зоря-Машпроект», ГП «ПО 
«Южный машиностроительный завод им.А.М.Макарова», ООО «Энергия», НПП «Монолит-Энерго», НТУ «Киевский политехнический институт», НТУ «Харьковский политехнический институт» в сферах очистки и опреснения воды, строительства ветряных энергетических систем, мобильного производства метанольной продукции. Как результат - подписание договоров на реализацию проектов с ТОО «НИИ «Казахстан Инжиниринг» и акиматами различных городов Казахстана, Карагандинским техническим университетом и Институтом сварки им.Б.Патона и др.

По словам бывшего посла Украины в РК (2010-2013) Олега Демина, перспективними направлениями для научно-технической кооперации являются машиностроение, авиастроение, горно-металлургическая, космическая отрасль и военно-техническое сотрудничество. На данный момент перспективными проектами совместной научной деятельности является создание наземной инфраструктуры системы спутниковой навигации, космическая система научного назначения для изучения ионосферы Земли, космическая система дистанционного зондирования Земли. Украина рассматривает возможность разработки совместно с Казахстаном спутников «Сич-3-0» и «Сич-С-Р» Перспективным является направление сотрудничества в сфере добычи газа. Как известно, энергетический фактор является определяющим для Украины в еe сотрудничестве с Казахстаном. И хотя сегодня Казахстан не имеет свободных активов для добычи газа украинскими компаниями, однако Украина является самой мощной базой для Казахстана в сфере поставок кадров, технологий и ноу-хау. «Сегодня мы выходим в Казахстан с предложением: наши новые технологии, наши специалисты, наши компании наравне с мировыми лидерами готовы брать участие в разработке газовых месторождений в Казахстане», - отмечает О. Демин [3].

Прослеживаются тенденции к интеграции ведущих вузов и научноисследовательских институтов двух стран. В частности, в 2014 году на базе физико-технического факультета ЕНУ завершилось создание радиотехнической лаборатории Института радиофизики НАН Украины (г.Харьков), работает совместная с ДНУ им.О.Гончара кафедра космических исследований и ведутся работы по созданию на ее базе лаборатории космической техники и новейших технологий. Перспективными направлениями сотрудничества университетов могут стать радиоэлектроника, физика, информационные технологии, биология, биотехнологии. Также, в соответствии с реалиями сегодняшнего дня, приобретает актуальность процесс активизации сотрудничества между аграрными университетами с целью улучшения работы агропромышленного комплекса как Украины, так и Казахстана. В частности, Казахский агротехнический университет им. С. Сейфуллина сотрудничает с Харьковским государственным университетом питания и торговли, Полтавской государственной аграрной академией, Национальным университетом биоресурсов и природопользования Украины, Белоцерковским национальным аграрным университетом. 
Следует отметить актуальность создания консорциумов и других научно-образовательных объединений. В 2015 году при поддержке МОН Украины в г. Ужгороде была проведена Международная научнопрактическая конференция «Мобильность образования, инновационная культура и социальная ответственность как ресурсы конкурентоспособности европейских университетов», с участием руководителей вузов Украины и Европы, Евразийского национального университета им. Л.Н. Гумилёва. Главным итогом мероприятия стало подписание Меморандума о создании Международного консорциума университетов, в который вошли 17 вузов из Польши, Румынии, Венгрии, Польши, Литвы, Словакии, Украины и Казахстана [4]. Целью созданного консорциума является налаживание и координация межинституционального сотрудничества в сферах академической мобильности, научных исследований, технологических разработок и инноваций, повышения конкурентоспособности в национальном и международном масштабах.

Интересными для казахской стороны являются передовые разработки научно-исследовательских организаций Украины в дистанционной геологоразведке, технологии электросварки живых тканей, с помощью которых делают «бескровные операции», разработки ученых в области возобновляемых источников энергии - солнечной, водородной, водной, вакуумной энергетики.

Подводя итоги, следовало бы подчеркнуть, что потенциал украинскоказахстанского сотрудничества в научно-технической сфере раскрыт далеко не полностью, а сегодня открываются ещё большие и новые возможности. Но дальнейшее развитие отношений в этой сфере требует политической воли руководства обеих стран, прежде всего Украины, внимания и привлечения значительных государственных средств, отсутствие которых препятствует реализации важных международных наукоёмких проектов.

\section{СПИСОК ИСПОЛЬЗОВАННЫХ ИСТОЧНИКОВ}

1. Договорно-правовое сотрудничество [Электронный ресурс] Посольство Украины в Республике Казахстан. - Режим доступа: http://kazakhstan.mfa.gov.ua/ru/ukraine-kz/legal-acts

2. Жумабаев А. «Казахстан-Украина: между прошлым и будущим». Київ: Довіра, 2010. - 367 с.

3. Абсалямова Н. Посол Украины: мы хотели бы видеть у себя больше казахстанцев // Экспресс Казахстан. - № 72, 24 апреля, 2011.

4. Евразийский национальный университет им. Л.Н. Гумилева / ЕНУ подписал Меморандум о международном консорциуме университетов [Электронний ресурс]. - Режим доступа: http://www.enu.kz/ru/info /novostienu/36108/?sphrase_id=475977 


\section{REFERENCES}

1. Dogovorno-pravovoye sotrudnichestvo [Contractual and legal cooperation]. Posol'stvo Ukrainy $\mathrm{v}$ Respublike Kazakhstan. Retrieved from: http://kazakhstan.mfa.gov.ua/ru/ukraine-kz/legal-acts

2. Zhumabayev, A. (2010) «Kazakhstan-Ukraina: mezhdu proshlym i budushchim» [Kazakhstan-Ukraine: between the past and the future]. Kyiv, 367.

3. Absalyamova, N. (24 aprelya, 2011) Posol Ukrainy: my khoteli by videt' $\mathrm{u}$ sebya bol'she kazakhstantsev [Ambassador of Ukraine: we would like to see more people of Kazakhstan]. Ekspress Kazakhstan. - № 72.

4. Yevraziyskiy natsional'nyy universitet im. L.N. Gumileva / YENU podpisal Memorandum o mezhdunarodnom konsortsiume universitetov [ENU signed a Memorandum on the International Consortium of Universities]. Retrieved from: http://www.enu.kz/ru/info /novosti-enu/36108/?sphrase_id=475977 